Alexander H. SLOCUM, Ph. D. Assistant Professor of Civil

Engineering, Massachusetts Institute of Technology

\title{
Development of the integrated Construction Automation Methodology
}


Abstract

Current research in construction automation is focusing on automat Ing Individual processes Instead of approaching the problem from a hlerarchlcal systems vlewpolnt; thus many systems being studied treat the construction site as a "hostile" environment and Incorporate many sensors to extract Information from the bulliding. As a result, sensor and sIgnal processing technology can be a 1 ImItIng factor In the design of machines to automate bullding processes. However, if integration and automation of the construction process are approached from a systems vlew, then existing technology can bo used to design economical mach Ines to automate many construction processes, and to coordinate and Integrate their use within the construction environment. A new design methodology, the Integrated Construction Automation Methodology (ICAM), Is presented here to assist in achleving high levels of integration and automation using existing technology. 


\section{Intreduction}

The U.S. construction Industry has had a net loss of productivity of almost 3\% a year since 1972 [1]. To reverse this trend, the Industry must automate. Automation is no longer an Issue of labor/management ac- . ceptance, it is required for survival. As the manufacturing Industry has learned, "Computers or programmable devices in the hands of a highly motivated workforce appear to be the solution to many of our manufacturIng challenges" ${ }^{1}$.

A construction site is a complex system Involving many disclpIInes operating sImultaneously; thus automating construction processes and integrating them Into the overall process wIII require IdentIfIcation and decomposition of system and subsystem tasks using a hlerarchlcal control strategy Implemented through a local area network at the site. Thls type of control strategy will allow real time modiflcation of processes and thelr completion sequence; thus making the system adaptive to the of ten varying construction environment.

Although strategles for Integrating and automating the manufacturing process and the construction process are similar (e.g. hlerarchlcal control of computer controlled machlnes), the construction

1 R.J. Eaton, General Motors Vice Presldent, Advanced Product \& Manufactur Ing Englneer Ing at the first Manufacturing Automation Protocol (MAP) demonstration, Natlonal Computer Conference, July 1984. 
process takes place where workers and machines must function in of ten poorly deflned, harsh operatlonal environments. Thus to Increase the chances of success, teamwork and cooperation among machlnes and processes must be designed In and Integrated at the systems level.

To help coalesce the fragmented construction Industry, a method of attalning these goals is belng developed by the author. The Integrated Construction Automation Methodology (ICAM) wIII help automate the construction process by integrating bullding, machlne (robot), and process design on a systems level. InIt|ally It wlll be developed and demonstrated for application to automation of large buliding construction.

This approach is currently belng studled by the author at MIT. The following describe in greater detall the problem definltion and the methods belng developed to address the Issues Involved In Integrating and automating construction processes.

\section{Problem Definition}

Although sophlstlcated software tools are avallable for manaing construction projects, success of the project still relles on subcontractors and workers to carry out tasks and report the results. This results in Islands of modernlzation that lack compatiblilty at the management (computer software/hardware) level and the Implementation (machlne and process automatlon) level.

Currently there does not seem to be a coordinated effort between bullding designers, contractors and machine deslgners to automate the construction process on a systems level. As a result, a trend is formIng towards development of Independent automated machInes whIch require 
sophistlcated sensor and Information processing technology. Hence these "machInes" wIII-bo costly and difflcult to Implement in practlce because of current technological I ImItations.

In order to overcome this problem of fragmentation and expens Ive automation, standard Interfaces for construction integration between computer software and hardware tools currently are belng Ident Ifled, developed, and syntheslzed. Thls wIII allow computers to schedule, coordinate, and control project tasks. Under computer control, stat istIcal quality control data can be obtalned, thereby allowing for opt ImIzation of construction processes. In addition to computer scheduling of project tasks, computer controlled machlnery for automatIng construction processes is also belng developed by the author.

The construction Industry has consldered its working environment too hostlie to be economically automated (e.g. dirt and temperature extremes as well as III-defIned processes). Indeed ad-hoc automat Ion wIII be expenslve and wIII thus have IImIted use. ThIs paper wIII show that It is possible to bring the construction process under control if integration and automation are approached from a systems design level.

\subsection{Oblectlves of ICAM}

In manufacturing, the size of the machine dominates the process; bullding construction processes, on the other hand, are usually much larger than the machines. The key to construction automation, therefore, Is to use the bullding system Itself as a "machine conglomerate" with machine elements as distinct degrees of freedom within the "machine conglomerate" (bullaling). Thus the objectlves of ICAM are: 
1) Develop a design methodology to Integrate bullding design with machlne design for automation. Application of the methodology should yleld a matrix of functional speclficatlons for machlnery and processes needed to automate a partlcular construction project.

2) Develop basis for a hlerarchlcal control system for control-. IIng an automated construction site. Speclflcaliy, a generlc sensory Interactive control system and data base for use with famllles of computer controlled machlnes.

\subsection{Research Trends in construction Automation}

The term "construction automation" conjures up images of androlds running around with hammers and shovels. Simliarly, with the advent of computer controlled machlnery, people envisloned multipurpose androld type robots producing all our goods and services. However, early forecasts of widespread use of autonomous robots by the mld 1980's were too optImIstic [2]. A human's sensory system and Intelligence are not easily duplicated by machines. Thls experlence led to modeling and design of well defined processes whlch could be executed by simple computer controlled machines $[3,4]$.

In a laboratory environment, mechanlcal designs of robots are capable of performing most manlpulating operations that would be required for automating many construction processes. However, current designs are too complex for application in a hostlie construction environment. Furthermore, current sensor and Information processing technology is very IImIted In Its abllity to adapt to varying environments and locatlons. Thus it is not recommended that an attempt be made 
to adapt general purpose robots for use In a construction environment. Two papers $[5,6]$ provide an excellent overvlew of research in construction automation, and they affirm that the Japanese are presently leaters In this fleld.

The Japanese are leaders In construction robotlcs because they have an aggressive research, development, and Implementation program. They realize the power of combining electronlc and mechanical systems to create "smart" speclal purpose machlnes (1.e. mechatronlcs). For example, they have used their "balanced earth tunneling method" to bulld a tunnel In San Franclsco using remote controlled machines. Schimizu Construction and Kobe steel have developed a robot for apply Ing rock wool fireproofing Insulation to steel structures. The Japanese are also good at developing large systems, such as entire factorles on a barge whlch they can ship to location (e.g. a pulp mIII for use in the Amazon).

The Japanese, however, do not seem to be focussing attention on a long term goal of a coordinated systems approach to construction Integration and automation, based on hlerarchlcal computer control of the entire construction process. They are In the process of developing a number of construction robots for varled applicailons (non-integrated) Including [7]:
1) Robots for erecting steel structures,
2) Robots for welding at site,
3) Robots for finishing concrete floors,
4) Robots for erecting and dismantling scaffolding,
5) Robots for cleaning onsite,
6) Robots for applying sealant to exterlor walls, 


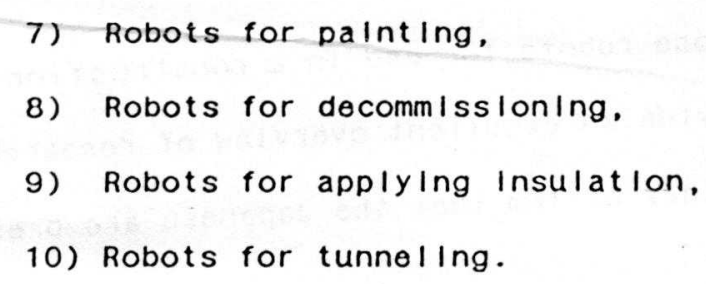

Reference has not been found with regard to application of a computer controlled machlne to help construct (assemble) a bullding in the U.S. The trend seems to be towards Increased use of prefabrlcated sectlons, many st 111 made by hand offslte, that are assembled by hand onslte. However, U.S. researchers lead in advanced robot design and artIflclal Intelligence technologles and are applying them, for example, to moblle robots for operation in nuclear and undersea environments $[8,9]$. Researchers at Carnegle Mellon Unlversity are working on robots for cleanlng up Three MIle Island. Also researchers at stanford UnIversity in cooperation with UnImation have added wheels to a six axis robot to enable it to travel $40 \mathrm{ft}$. and stop w/th!n Inches of Its target, but accuracles on the order of 0.050 " are needed for most bullding construction processes.

\subsection{Conclusions on ADollcatlons of State-of-the-Art Robotles Technology te construction Automation}

The absence of technology requlred to fully emulate human construction workers will preclude full scale automation of existing construction processes on an Individual basis. However, If machines for automating construction processes are designed in conjunction with the bullding, then existing technology can be applied to provide a far greater degree of automation than is currently belleved to be possible. This conclusion is based on the following observations: 
1) Global position of a robot within a buliding is not easily achleved using onboard sensors; however, position can be deterinined with respect to structural members or radio frequency emitting wires in a concrete floor.

2) The lack of avallable vision and tactlie Information processIng technology can be compensated for by keepling the bullding slte clean and well ordered. Also, by design for robotlc assembly, many processes can be automated without the need for elaborate vision systems.

3) The dexterlty of a human construction worker cannot be duplicated by any machine, nor are designs IIkely to be developed In the near future.

Mechanlcal and electro-mechanlcal systems are princlpal IImIting factors In Integrating and automating construction processes. Another IImIt Ing factor is the methods by whlch the mechanlcal systems are to be controlled.

\section{Artiflelal Intelligence and Expert systems for controlling Automated}

\section{Mach Inery}

In the early $1960^{\circ} \mathrm{s}$, some researchers envisloned computers as soon being able to act as unlversal language translators. ThIs goal was never met because the rules of translation are not stralghtforward, they often require creative thought. SImIlarly. Artificlal Intelilgence researchers envisioned thinking computers which could be used to control disordered processes. Thls goal has not been met, because Intel I gence Is beling able to come up with new conclusions from old facts, where these conclusions are not based on IF THEN conditions. It would seem 
that the baslc physlcs of computers and computer languages (they are blnary yes/no systems) wlll seem to IImlt them to applicatlons of problem solving paradlgms (Expert Systems) [10].

It is true that expert systems will be a key to loosening required restralnts on a process and giving machlnes more freedom to operate In less defined environments, but artiflclal Intelilgence to declde what to do In a new type of sltuation will not be avallable for many years [11]. Once expert systems are developed, If the machlne encounters unfamlllar difflcultles, the machine can supply data to a remote operator who can assess and correct the sltuation.

\section{1_-Hlerarchlcal centreL Strategles for centrelllng an_Autemated} censtruction site

The principle of hierarchlcal control is based on a tree structure whereln each computational module has a single superlor and one or more subordinate modules (or Interfaces to mechanlcal systems). Goals and plans are generated at the hlghest level whlch are decomposed at each lower level Into subgoals. ThIs continues untll work requlred to complete the overall goal is distrlbuted to simple machines in the form of simple tasks [12]. Informatlon gathered during execution of the task Is reported to the control system for statistical quallty control analysis. Thls type of control strategy is needed to allow the system to adapt to the of ten varying construction environment.

On a large research scale, a hlerarchlcal control strategy has been Implemented In the Automated Manufacturing Research Facllity at the Natlonal Bureau of Standards [13]. In order to apply hlerarchlcal control strategles to control an automated construction site, many 
developments are needed such as: a central database, an understanding of the processes (to the polnt where the processes can be automated), a rugged Local Area Network (LAN), and computer controlled (or human asslsted) machInes.

For a famliy of machInes ta complete a group of tasks, they wIII have to share Information. Thls Implies the development of a generlc sensory Interactive control system for use with famllies of computer controlled machines. The structure of the controller would be hlerarchlcal and modular. For the machine to be able to react to changes in Its environment in a reasonable amount of time the controlier would operate In real-time. Note that only the lowest level of the controller, which Interfaces directly to each machine, would be machine specif IC.

The machIne control systems would have the capabllity of Interfacling with a central controller. The central controller would be a more elaborate structure of the baslc generlc controller. The machine controllers would have the capabllity of accepting data from a data base within the central controller. The data would be high level command Instructions.whlch the controllers would decompose Into subtasks to be performed by the varlous elements of the machines such as sensors and actuators.

A hlerarchical structure for the use of task decomposition Is helpful In modularlzing the complicated systems, In partlcular the central controller. By making the system modular, one can add or make changes to the levels of the system easlly. DIfferent machlnes wlII be performing Jobs whlch require different sensory and actuator systems to Interface to the machine's control system. Each sensory and actuator 
system will require a separate module within the control level with which it intorfaces.

Development of this type of control system is needed for the control of a famliy of sequentlally operating construction robots (or any other machine famliy). In addition to recelving instructions from the central controller, each member of the machine family would need to be capable of feeding back Information about its completed process to the data base. The Information would then be used by a following machlne to compensate for errors In a prevlous machlne's process. Thus, the feedback Information would be used to facllltate machine learning to enhance online quality control.

\section{Develeoment of the Integrated Construction Automation Methodology} (ICAM)

The Integrated Construction Automation Methodology (ICAM) is a systems design concept that Integrates design, functionality, and constructablilty using the princlple of harmony to avold adverslty between automated machines and the bullding, thus allowing Integration of bulldIng design with machlne design to automate construction.

"Harmony" between a machine and a process requires the machlne to execute the process in as simple a manner as possible, and without having the results generate condltions adverse to other mach Ines whose processes may bulld upon the first. In fact, sequentlal processes must be able to rely on the quality of the first process so the next mach ine and process can be slmplifled. "Adverslty" between a machlne and a process is requiring the machine to be able to process extra Information In order to accomplish the Job. An example is to require robots to have 
vision to plck parts from a bin. It is much simpler and more economical to present the parts to the robot in an ordered manner.

An example of "Harmony" In construction automation is to use the bullding system Itself as a "machlne conglomerate" with machlne elements as distinct degrees of freedom within the "machlne conglomerate" (bulldIng). Since bulldIngs are carteslan systems, Instead of trylng to bulld a machine and guldance system to move in three dimenslons, one can bulld the steel framework as a glant serles of machine axes with integral bar codes describing location, function, etc. As a machlne completes a task, It may leave a coded message that is used to gulde following machines, with all Information stored (and cont Inually updated) In a central database. ThIs requires the bullding and Integration/automation plan to be designed together as a system.

In order to develop this type of systems approach, the problem must be defined with respect to goals and technology. Thus the first step towards Integration and automation of bullding construction is to Ident Ify and classlfy types of deslgns, processes, and tools currently used with respect to how they can be automated and Integrated Into the global process, namely:

1) What are the short and long term beneflts that wlII result from varlous levels of automation of a process (machine design and possible modiflcation of the process) using existing technology.

2) What are the long term benefits of developing new technologles to automate a process, or develop an entirely new process that can be automated, whlle meeting functional performance specif Icat lons. 
3) WIII the system lend Itself to partial or total Integration with the global construction process.

Also related is the type of research (short, addlum. and torg term) required to automate and Integrate an IndIvIdual process, whIch can be assessed based on the following:

A) Can the process be automated and integrated in Its present state using appllcatlons of existing technology? (short term, 1-5 years). In the short term, automation of specific processes wIII be IImIted by present technology to those that require a great deal of relat Ive accuracy and take place along well deflned continuous paths (no corners). Processes whlch do not require accuracy but have discont Inuous paths can also be automated.

B) Is the process fundamentaliy simple and efflcient, requiring only skilled labor (and undeveloped technology to emulate the skllled labor) to execute it? (medlum term, 5-10 years).

C) Is the process too complex to be automated and integrated using current technology or technology that is IIkely to become avallable in the near future? (long term, 10 + years).

Among the processes Involved In design and construction of large bulldings, the following are rated as to the time frame required to automate and Integrate the process (s-short term, m-medlum term, I-long term):

1) Functional speclfications of bullding defined (s-1).

2) Bul IdIng form and detalled plans deflned by archltectural/englneer Ing f Irm:

a) bullding's site $(s-1)$ 
b) bullding's structural deslgn $(s-1)$

c) bullding's exterlor (s-1)

d) bullding's Interlor (s-1)

3) Prepare slte:

a) excavation and grading (1)

b) utIIIty connectlons (water, sewer, electr|cal) (I)

c) road bullaing (1)

4) Construction of the bullding:

a) foundation (1)

b) structural skeleton (m)

c) construction of the Interlor:

1) Interlor wall framing (s)

2) ductwork (m)

3) plumbing and electrical (i)

4) drywall (s)

5) tape drywa II (m)

5) paint interlor (s-m)

6) floor ling (s-m)

6) elevators (1)

d) construction of the exterior:

1) facade $(m-1)$

2) windows (m)

3) palnt Ing/weatherproof Ing (m)

4) roofing (m)

If executed Individually, automating most of the above processes wIII require accurate positioning capablilties, assessment of the environment, and emulation of skllied manual labor. Thus it would be very 
difflcult to automate many of these steps on an Individual basls. If designed and executed as a bullding system, however, the task of automatIon becomes more tractable.

From this polnt, ICAM wIII assist in the systems and machine design phase. Speclfically, ICAM wIII help evaluate elements of a design matrix of requirements (functional speclfications) to automate and Integrate construction processes by executing the following functions :

1) Specify functional requirements for the bullding, and develop conceptual designs of the bullding.

2) Identify bullding construction processes.

3) Formulate machlne and process design matrlx of functional speciflcatlons for automating and integrating processes (wish (lst).

4) Formulate a list of technologles (exlsting and/or future) required to automate existing processes. Evaluate the degree of Integration (total or partial) that can be attained.

5) Assess avallable technology (and economlcs of Implementation with respect to 4 ).

6) Evaluate physical Information avaliable from processes that may also be used to gulde other processes ( $\theta . g$. the position of a structural beam).

7) Opt ImIze machlne and process design design matrix by match Ing sources of Information and processes whIch need simliar information in order to be executed. (I.e. match information that Is avallable or lacking).

8) Design, bulld and Integrate test systems. 
Steps 6 and 7 are critlcal to adapting existing technology to the problem of Integrat Ing and automating construction processes. Once the deslgn matrix is opt ImIzed, a detalled execution plan can be formulated for the entire system because the matrix IdentIfles Inputs, outputs and technology required for machines to automate speclf Ic processes with In the system.

\section{Conclusions}

ICAM WIII be a first step in developing an organlzed systems approach towards automating the often fragmented construction process. Completion of this research can have the following Impact in the construction Industry:

1) It will help to organize and Integrate the bullding, process, and machine design processes; thus help Ing to el ImInate the fragmentation that currontly exists.

2) In the short term, large Increases In productivity in some processes wIII be reallzed.

3) In the long term, ICAM wIII lead to development of an expert system and machinery - as approprlate technology matures that wIII optImIze design and construction of entire bullding systems, with resultant dramatlc Increases In productivity. The methods developed wIII a Iso be adopted for use In automating other large scale operations.

UIt Imately, adoption of ICAM WIII lead to an Integrated constructIon slte that wIII conslst of workers, and computer controlled machlnes all coordinated by a central operatlons computer. Using a hlerarchlcal control strategy, the computer wIll Instruct men and machlnes to perform 
tasks whlch may be decomposed Into sub-tasks untll they are physlcally completed. Progress wIII be cont Inually reported back to the central computer which will use thls information to update scheduling of tasks. In addition, It will allow the entire bullding process to be statistically analyzed and opt ImIzed [14].

Furthermore, ICAM WIII provlde a new systems englneering tool for developing automated and Integrated construction processes. Examples of additional work needed are: ArtIflclal Intelligence researchers to develop expert systems to apply ICAM for use by the designers of bulldings and machines. As a result, sensors and information processing researchers will have areas of critlcal research ldent lf led (s Ingularities in the design matrlx whlch wlil require a human to correct). Also, mechanlcal deslgn researchers wlll häve functlonal speclfications defined so they can concentrate on machlne design and not have to try and figure out a process that is forelgn to them.

ICAM can enable the construction Industry to achleve gains in productivity, quallty and safety. It wIII do thls by laying the foundation for Computer Integrated Construction (CIC) systems that will control and automate the bullding and deslgn process from conception thru construction. Ultimately It wlll also help tle together all the professlons Involved in the complex bullding process. 


\section{Beferences}

[1] F. Moavenzadeh, "Construction's HIgh-Technology Revolution", Iechnelegy Revlew, Vol. 88, No. 7 (Oct. 1985) pp 32-41.

[2] M. Kassler, "Robots and MInIng: The Impllcatlons for Australlan Industry In the 1980's", Rebet/ca, Vol. 31985 pp 13-19.

[3] J.F. Engleberger, "Robotlcs 1989", Rebetles Ieday, Dec. 1984, pp $57-59$.

[4] R.R. Schrelber, "Robotlcs Research: The Next FIve Years and Beyond", Rebotles Today, Dec. 1984, pp 54-55.

[5] B.C. Boyd, "Automation and Robotlcs for Construction", Jeb__ef censtructlon Englneerling and Management, Sept. 1985, Vol. 111, No. 3. pp 190-207.

[6] A, WarszawskI, D. Sangrey, "Robotlcs In Bullding Construction", Jou. of construction Engineering and Management, Sept. 1985, Vol. 111, No. 3, pp 260-280.

[7] E. Suzukl, "The Vlew From Japan of Future Bullding Programs",

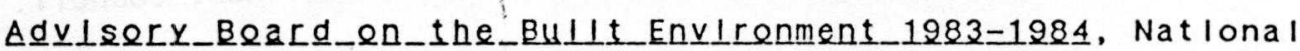
Research Councl1, pp 13-27

[8] R.R. Schrelber, "The U.S. Robot Industry", Rebotles Teday, Oct. 1985, pp 35-42.

[9] R.R. Schrelber, "Robotics Unlimited: Reaching Beyond the Factory", Robotles Today, Dec. 1984, pp 43-47.

[10] P.H. WInston, Artificlal Intelllgence, AddIson Wesley Publ. 1984.

[11] P.T. Rayson, "A Revlew of Expert systems Princlples and Thelr Role In Manufacturing Systems", Robotlca, Vol. 3 Part 4, Oct-Dec 1985, pp 279-287. 
[12] J.S. Albus et-al, "Hlerarchlcal Control for Robots In an Automated Factory". 13th ISIR/Robots symoeslum. ChIcago III. AprII 1983.

[13] J.A. SImpson et-al. "The Automated Manufacturing Research Facllity at the Nat Ional Bureau of Standards", Jeu. Manufacturing systems, 1982 Vol. 1. No. 1, pp 17-31.

[14] Report from The 1984 Werkshep on Advanced Technelegy for_Bu $\perp \perp$ ding Deslgn and EnglneerIng, BIdg. Res. Board, Nat. Res. Councll.

\author{
Alexander H. Slocum, Ph.D. \\ Assistant Professor of Civil Englneering \\ Massachusetts Instltute of Technology \\ Cambrldge Massachusetts, USA
}

